\title{
Characterization of the functional and growth properties of long-term cell cultures established from a human somatostatinoma
}

\author{
G Galli ${ }^{1}, R$ Zonefrati ${ }^{1}$, A Gozzini ${ }^{1}, C$ Mavilia ${ }^{1,4}, V_{\text {Martineti }}{ }^{1,4}, I_{\text {Tognarini }}{ }^{1}$, \\ G Nesi ${ }^{2}$, T Marcucci $^{3}$, F Tonelli ${ }^{3}$, M Tommasi $^{3}$, C Casini Raggi ${ }^{3}$, P Pinzani $^{3}$ \\ and $M L$ Brandi $^{1,4}$
}

\author{
${ }^{1}$ Department of Internal Medicine, University of Florence Medical School, Viale Pieraccini 6, 50139 Florence, Italy \\ ${ }^{2}$ Department of Pathology, University of Florence Medical School, Florence, Italy \\ ${ }^{3}$ Department of Clinical Physiopathology, University of Florence Medical School, Florence, Italy \\ ${ }^{4}$ DEGENE Spin-off, University of Florence Medical School, Florence, Italy
}

(Requests for offprints should be addressed to M L Brandi at Department of Internal Medicine, University of Florence; Email: m.brandi@dmi.unifi.it)

\begin{abstract}
In somatostatinoma, a rare malignant somatostatin (SST)-secreting neoplasia, tumour regression is rarely observed, implying the need for novel antiproliferative strategies. Here, we characterized a long-term culture (SST-secreting cancer (SS-C cells)) established from a human somatostatinoma. High concentrations of SST and chromogranin A were released by SS-C cells and SST release was stimulated by depolarizing stimuli and inhibited by the SST analogue, octreotide. SS-C cells expressed mRNA for SST receptor (SSTR) subtypes 1, 2 and 4, being also able to bind native SST. Moreover, SS-C cells were positively stained with an antibody to SSTR2. SS-C cells also expressed interferon- $\gamma(\mathrm{IFN}-\gamma)$ receptor mRNA and measurable telomerase activity. Our findings indicate that in vitro exposure of SS-C cells to native SST-28, to octreotide, to IFN- $\gamma$, or to $3^{\prime}$-azido$3^{\prime}$ deoxythymidine (AZT), a telomerase inhibitor, results in inhibition of SS-C cell proliferation. Concomitant with growth inhibition, apoptosis was detected in SST-, octreotide-, IFN- $\gamma$ - or AZTtreated SS-C cell cultures. Taken together our results characterized native SST, SST analogues, IFN- $\gamma$ and a telomerase inhibitor as growth-inhibiting and proapoptotic stimuli in cultured human somatostatinoma cells. Based on these findings, the potential of SST analogues, IFN- $\gamma$ and AZT, alone or in combination, should be further explored in the medical treatment of somatostatinoma.
\end{abstract}

Endocrine-Related Cancer (2006) 13 79-93

\section{Introduction}

Somatostatinoma is a rare malignant neuroendocrine tumour, accounting for fewer than $1 \%$ of all gut and pancreatic endocrine neoplasia (Jensen \& Norton 1993), with preferential localization in the pancreas, followed by duodenum and jejunum (Konomi et al. 1990, Bordi et al. 1996). The lack of specificity of symptoms makes difficult an early and preoperative diagnosis of this tumour (Sassolas \& Chayvialle 1995). Therefore, in more than $85 \%$ of the cases the diagnosis is established when liver and lymph node metastases are displayed. Ex vivo and in vivo analyses of somatostatinoma tissues and cells showed the presence of somatostatin (SST) and interferon- $\gamma$ receptors (IFN$\gamma$-Rs), opening the possibility of treatment of metastatic disease with SST analogues and IFN- $\gamma$ (Angeletti et al. 1998, Detjen et al. 2002).

The availability of in vitro models of somatostatinoma cells would certainly increase the possibility of treatment with potential pharmacological agents. The only model of a cultured human SST-secreting cell line obtained from a neuroendocrine pancreatic tumour, QGP-1 cells, was described more than a 
decade ago (Iguchi et al. 1990). The QGP-1 cell line was characterized by a slow growth rate, by the production of SST, of carcinoembryonic antigen (CEA) and of small quantities of pancreatic polypeptide (PP) (Iguchi et al. 1990) and by the expression of functional IFN- $\gamma$-Rs (Detjen et al. 2002).

In this study we examined the functional and growth properties of long-term cell cultures of an SST-secreting cancer (SS-C cells) obtained from a primary human somatostatinoma. We also evaluated the response of SS-C cells to various physiological and pharmacological agents.

\section{Materials and methods}

\section{Patient's history}

Tissue samples were obtained from a female patient (aged 28 years) affected by malignant metabolic jejunal somatostatinoma after surgical removal of the tumour. The patient had neither a family history of endocrine pathology nor associated endocrinopathies. Diagnosis was made on the basis of clinical and biochemical characteristics of the patient in combination with (immuno)histochemistry of the primary tumour and of the liver metastatic tissues. Tests performed included RIA of hormones, computed tomography (CT), magnetic resonance imaging (MRI), octreotide scintigraphy, endoscopic ultrasonography, genetic mutational test for MEN1 gene, and immunohistochemical staining of tumour tissue. The patient gave her informed consent for the use of tumour material for research purpose.

\section{Materials}

SST-28 was purchased from Calbiochem (Langentigen, Switzerland); recombinant human IFN- $\gamma$ was purchased from Boehringer Mannheim (Mannheim, Germany); octreotide was supplied by Novartis (Basel, Switzerland); SST-28, octreotide and IFN- $\gamma$ were dissolved in $0.01 \mathrm{M}$ acetic acid containing $0.1 \%$ purified serum albumin and then stored at $-80^{\circ} \mathrm{C}$ as $1 \mathrm{mM}$ solutions. Fresh working solutions were prepared as new aliquots for each experiment. The Ultravision kit was from Lab Vision (Fremont, CA, USA); clone LKzH10 and anti-gastrin antibody from BioGenex (San Ramon, CA, USA); annexin V-FITC was obtained from Caltaq Laboratories (Burlingame, CA, USA); radioimmunological kits were: for somatostatin, cholecystokinin (CK) and substance P, from Euro-Diagnostica (Malmo, Sweden), for PP and gastric inhibitor peptide (GIP) from Phoenix Pharmaceutical (Belmont, CA, USA), for vasoactive intestinal peptide (VIP) from Diasorin (Stillwater, MN, USA), for calcitonin gene-related peptide (CGRP), from Peninsula Laboratories Inc. (Belmont, CA, USA), for glucagon from Adaltis (Casalecchio di Reno, Italy), for gastrin from Incstar Co. (Stillwater, MN, USA), for chromogranin A (CgA) from Schering S.A. (Cedex, France), for calcitonin from Scantibodies Laboratory Inc. (Santee, CA, USA), for neuron-specific enolase (NSE) from CIS Bio International (Cedex France), and for C-peptide and insulin from TecnoGenetics (Cassina de'Pecchi, Italy). Polyclonal antibodies against somatostatin, glucagon, gastrin, and PP were obtained from DAKO (Carpinteria, CA, USA), while those for synaptophysin and NSE were from Ventana Medical Systems Inc. (Strasbourg, France). TP53 gene mutation screening kit was purchased from Analitica (Padua, Italy). Clone AMV First-Strand CDNA synthesis kit was from Invitrogen Corporation (Carlsbad, CA, USA). RNAWIZ RNA Isolation Reagent was from Ambion, Inc. (Austin, TX, USA). The QUIAEXII kit was from Qiagen Inc. (Valencia, CA, USA) and puReTaq Ready-To-Go PCR beads from Amersham Biosciences Corp. (Piscataway, NJ, USA). Annexin V-FITC was from Caltaq Laboratories. The ligand, 3-[ $\left.{ }^{125} \mathrm{I}\right]$ iodotyrosyl ${ }^{25}$-somatostatin$28\left(\mathrm{Leu}^{8}, \mathrm{D}-\mathrm{Trp}^{22}, \mathrm{Tyr}^{25}\right)$, was obtained from Amersham (Milan, Italy) and was used at a final concentration of $0.1 \mathrm{nM}$. An antibody to SST receptor type 2 (SSTR2) was purchased from Biotrend (Schwabhausen, Germany). Caspase-3 colorimetric assay was from R\&D Systems (Milan, Italy).

All other compounds were from Sigma-Aldrich Srl (Milan, Italy), unless otherwise specified.

\section{Immunohistochemistry and immunocytochemistry}

The surgical specimen was fixed in $10 \%$ neutral buffered formalin before being processed in paraffin. Immunohistochemical studies were performed using the streptavidin-biotin-peroxidase method (Ultra Vision kit; LAB VISION, Freemont, CA, USA) with diaminobenzidine as the chromogen and haematoxylin as the nuclear counterstain. A panel of antibodies against the following antigens was used: $\mathrm{CgA}$ (clone LK2H10; BioGenex; predilute; microwave antigen retrieval); synaptophysin (polyclonal; Cell Marque, Hot Springs, AR, USA; predilute; Ventana NexES immunostainer, Ventana Medical System Inc., Strasbourg, France; microwave antigen retrieval); NSE (clone E27; Cell Marque; predilute; Ventana NexES immunostainer; microwave antigen retrieval); SST (polyclonal; DAKO, Carpinteria, CA, USA; 
dilution 1:4); insulin (polyclonal; DAKO; predilute); glucagon (polyclonal; DAKO; dilution 1:4); gastrin (polyclonal; BioGenex; dilution $1: 150$ ); and PP (polyclonal; DAKO; dilution 1:1000). Positive immunohistochemical controls included normal human tissues to which the appropriate antisera were added. Negative controls were performed by substituting the primary antibody with a non-immune serum of the same concentration.

Immunocytochemical localization of SSTR2 was performed in 4th passage SS-C cells grown on glass cover slips coated with poly-D-lysine $(50 \mu \mathrm{g} / \mathrm{ml})$. After washing with ice-cold Tris-buffered saline (TBS), cells were immediately fixed with $4 \%$ paraformaldehyde in PBS pH 7.2 for $20 \mathrm{~min}$ at room temperature. Fixed cells were washed with TBS (twice for $5 \mathrm{~min}$ each) and incubated at room temperature with $3 \%$ normal goat serum in TBS for $30 \mathrm{~min}$. Receptors were detected by incubation at $4{ }^{\circ} \mathrm{C}$ with SSTR 2 antibody $(1: 1000$ in TBS containing $0.2 \%$ Tween-20, $10 \%$ non-fat dry milk, and $10 \%$ glycerol). Cells were subsequently rinsed, twice for $5 \mathrm{~min}$ each, with TBS and incubated at room temperature for $30-60 \mathrm{~min}$ with FITCconjugated goat anti-rabbit antibody $(1: 100)$. After two additional rinses with TBS ( 5 min each), the cover slips were mounted on glass slides with Mowiol/ DABCO. The cells were imaged by epifluorescence microscopy. Controls were represented by the absence of primary antibody and by human skin fibroblasts.

\section{Cultures of human somatostatinoma cells}

Primary somatostatinoma tissue was surgically removed from jejunum, and metastatic tissue was removed from the liver. Tissue samples were obtained in accordance with a protocol approved by the Institutional Review Board for human studies. The patient provided informed consent as dictated by this protocol.

A fragment of the primary tumour and of one of the removed liver metastasis were collected in sterile conditions and transported to the laboratory. Tissue was minced into small fragments and digested overnight at $37^{\circ} \mathrm{C}$ with $0.3 \mathrm{mg} / \mathrm{ml}$ collagenase type II in Coon's modified Ham's F12 medium. Digested tissue fragments were gently centrifuged $(500 \mathrm{~g})$ transferred in Coon's modified Ham's F12 medium for mechanical dispersion and successively centrifuged at $500 \mathrm{~g}$. The pellet was resuspended in Coon's modified Ham's F12 medium supplemented with $20 \%$ fetal calf serum (FCS) plus antibiotics, distributed in plastic culture dishes at a density of $5 \times 10^{5}$ cells $/ 100 \mathrm{~mm}$ dish, and cultured at $37^{\circ} \mathrm{C}$ in humidified $95 \%$ air $/ 5 \% \quad \mathrm{CO}_{2}$ atmosphere.

Phase contrast light microscopy was employed to examine the density and the morphological features of somatostatinoma cells.

\section{Chromosome analysis}

Cells were treated with colcemid at a final concentration of $10^{-6} \mathrm{M}$ for $12 \mathrm{~h}$ before harvesting. After hypotonic treatment for $30 \mathrm{~min}$ at $37^{\circ} \mathrm{C}$ in $0.75 \%$ sodium citrate solution, the cells were fixed in methanol: acetic acid $(3: 1)$. Giemsa-stained specimens were examined for chromosome number, using more than 300 metaphase cells.

\section{Determination of neuropeptides in culture media}

To determine basal secretion of SST, CgA, glucagon, CGRP, calcitonin, insulin, C-peptide, gastrin, PP, GIP, CK, VIP, histamine, substance P and NSE, the cells after 7 days (1st passage), 40 days (5th passage), and 60 days (8th passage) in culture were detached from $100 \mathrm{~mm}$ culture dishes by trypsin solution $(0.25 \%$ in PBS) treatment and plated into $35 \mathrm{~mm}$ dishes. After $24 \mathrm{~h}$ incubation cells were exposed for $30 \mathrm{~min}$ to Coon's modified Ham's F12 medium, the medium was then changed and the cells were finally incubated for $1 \mathrm{~h}$ in Coon's modified Ham's F12 medium. Then the medium was taken, centrifuged and stored at $-80^{\circ} \mathrm{C}$ and the cells detached by trypsin and counted by haemocytometer. Negative controls were represented by Coon's modified Ham's F12 medium exposed for $1 \mathrm{~h}$ to plastic dishes alone. Positive controls were represented by Coon's modified Ham's F12 medium added with known quantities of human SST and exposed for $1 \mathrm{~h}$ to plastic dishes. Media from cell cultures were diluted from $1: 10$ to $1: 1000$ in PBS to allow better evaluation of peptide content. All samples from the same experiment were measured in the same assay. The results were expressed as $\mathrm{pg} / 10^{5}$ cells per $\mathrm{h}$. Absolute per cent variation from control data are reported as means \pm s.D.

Effects of high $\mathrm{K}^{+}(50 \mathrm{mM})$, theophylline $(10 \mathrm{mM})$ and octreotide $(1 \mu \mathrm{M})$ on the release of SST from SS-C cells were determined in SS-C cells at the 1st passage. The cells were plated into $35 \mathrm{~mm}$ dishes $\left(3 \times 10^{5}\right.$ cells/ dish) after trypsin treatment and a release experiment was performed on the $3 \mathrm{rd}$ day after plating. The cells were washed twice with PBS and incubated for $1 \mathrm{~h}$ in the presence or absence of test substances in the medium. Then, the medium was taken and stored at $-80^{\circ} \mathrm{C}$ until analysis. 
Table 1 Primers used in RT-PCR analysis

\begin{tabular}{lllc}
\hline mRNA species & \multicolumn{1}{c}{ Upstream primer } & \multicolumn{1}{c}{ Downstream primer } & $\begin{array}{c}\text { Fragment } \\
\text { size (bp) }\end{array}$ \\
\hline$\beta-A c t i n$ & GACCTGACTGACTACCTCATGAA & CTTCATGATGGAGTTGAAGGTAG & 303 \\
IFN- $\gamma$ & TGGCTTTTCAGCTCTGCATC & TCTCCACACTCTTTTGGATGC & 64 \\
IFN- $\gamma$-R1 & GTCCTCAGTGCCTACACCAACTAA & CCACACATGTAAGACTCCTTC & 251 \\
IFN- $\gamma$-R2 & CGAAGATTCGCCTGTACAACGCA & GTCACCTCAATCTTTTCTGGAGGC & 594 \\
\hline
\end{tabular}

Oligonucleotides sequence is in $5^{\prime}-3^{\prime}$ orientation.

\section{RNA preparation and RT-PCR}

Total cellular RNA was extracted from primary cultures of SS-C cells at the 2nd passage by using RNAWIZ RNA Isolation Reagent, according to the manufacturer's instructions. Briefly, $1-2 \times 10^{6}$ cells were disrupted and homogenized in $1 \mathrm{ml}$ denaturing solution. The lysate was then mixed with chloroform and centrifuged. After phenol/chloroform extraction, the RNA was precipitated from the aqueous phase with isopropanol, washed with $75 \%$ ethanol and airdried. The pellet was then dissolved in RNase-free water and stored at $-80^{\circ} \mathrm{C}$ until required. Since no RNA isolation method is capable of consistently producing RNA free of contaminating DNA at the level of RT-PCR detection, in order to avoid any amplification from genomic contamination, the samples were pre-treated with $1 \mathrm{U}$ of RNase A/DNase free $(12.8 \mathrm{U} / \mu \mathrm{l})$ at $37^{\circ} \mathrm{C}$ for $30 \mathrm{~min}$ and heat-inactivated at $68^{\circ} \mathrm{C}$ for $10 \mathrm{~min}$. The yield of RNA was calculated by spectrophotometry and to check RNA quality, $1 \mu \mathrm{g}$ of each RNA sample was analysed by agarose gel electrophoresis and visualized on UV light.

IFN- $\gamma$, IFN- $\gamma$-R1, IFN- $\gamma$-R2 and $\beta$-actin (housekeeping gene) mRNA expression was evaluated by RT-PCR in SS-C cells at the 2nd passage and on previously collected human normal $\mathrm{T}$ lymphocytes, used as positive control for IFN- $\gamma-\mathrm{R} 1$ and IFN- $\gamma-\mathrm{R} 2$. For IFN- $\gamma$, which is not constitutively produced by $\mathrm{T}$ cells, an oligonucleotide (457 nucleotides, from position 135 to 591, referred to Genbank accession number NM_000619) probe was used. First-strand cDNA was synthesized with $1 \mu \mathrm{g}$ total RNA using the Clone AMV First-Strand cDNA synthesis kit, according to the manufacturer's protocol. Briefly, $1 \mu \mathrm{g}$ total RNA was reverse transcribed in $50 \mathrm{mM}$ Tris acetate ( $\mathrm{pH} 8.4$ ), $75 \mathrm{mM}$ potassium acetate, $8 \mathrm{mM}$ magnesium acetate, $4 \mu \mathrm{g} / \mathrm{ml}$ BSA, $1 \mathrm{mM}$ each deoxyribonucleoside triphosphate, $5 \mathrm{mM}$ dithiothreitol, $2 \mathrm{U} / \mu \mathrm{R}$ RaseOUT recombinant ribonuclease inhibitor using $0.75 \mathrm{U} / \mu \mathrm{l}$ cloned avian myeloblastosis virus (AMV) reverse transcriptase (RT), and $2.5 \mu \mathrm{M}$ Oligo $(\mathrm{dT})_{20}$ as first-strand cDNA primer in a total volume of $20 \mu \mathrm{l}$. RT reactions were carried out at $50^{\circ} \mathrm{C}$ for $60 \mathrm{~min}$, followed by RT heat-inactivation at $85^{\circ} \mathrm{C}$ for $5 \mathrm{~min}$ and quick-chilled on ice. The resulting cDNA was stored at $-20^{\circ} \mathrm{C}$ for subsequent amplifications. In the second step, IFN- $\gamma$, IFN- $\gamma-\mathrm{R} 1, \mathrm{IFN}-\gamma-\mathrm{R} 2$ and $\beta$-actin expression was evaluated by PCR performed in separate tubes using primers specific for the genes of interest (Table 1) and puReTaq Ready-To-Go PCR beads. $\beta$-Actin was used as a constitutively expressed gene product for comparison of IFN- $\gamma$, IFN- $\gamma-\mathrm{R} 1$ and IFN- $\gamma$-R2 mRNA quality and concentration in each sample. Parallel RT-PCRs without added RT were performed to check genomic DNA contamination of samples. RT products $(2 \mu \mathrm{l})$ were amplified with $2.5 \mathrm{U}$ puReTaq DNA polymerase, $10 \mathrm{mM}$ Tris- $\mathrm{HCl}$ (pH 9.0), $50 \mathrm{mM} \mathrm{KCl}, 1.5 \mathrm{MgCl}_{2}, 200 \mu \mathrm{M}$ dATP, dCTP, dGTP and dTTP, 6 pmol of each pair of primers and sterile high-quality water to a final volume of $25 \mu \mathrm{l}$ as follows: initial denaturation for $4 \mathrm{~min}$ at $94^{\circ} \mathrm{C}, 35$ cycles of amplification, $30 \mathrm{~s}$ of denaturation at $94^{\circ} \mathrm{C}$, different annealing temperatures for each pair of primers (IFN- $\gamma / 60^{\circ} \mathrm{C}$, IFN- $\gamma-\mathrm{R} 1 / 62^{\circ} \mathrm{C}$, IFN$\gamma$-R2 $/ 60^{\circ} \mathrm{C}$, and $\beta$-actin $\left./ 60^{\circ} \mathrm{C}\right), 30 \mathrm{~s}$ of extension at $72^{\circ} \mathrm{C}$, and a final elongation step of $7 \mathrm{~min}$ at $72{ }^{\circ} \mathrm{C}$. Specific sets of upstream and downstream PCR primers for IFN- $\gamma$, IFN- $\gamma$-R1, IFN- $\gamma$-R2 and $\beta$-actin were designed on the basis of cDNA published sequences of Genbank Database: $5^{\prime}$-tggcttttcagctctgcatc and $3^{\prime}$-TCTCCACACTCTTTTGGATGC (amplified fragment of $251 \mathrm{bp}$ ) for IFN- $\gamma$-spanning exons 1-3, 5'-GTCCTCAGTGCCTACACCAACTAA and 3'-CCACACATGTAAGACTCCTTC (amplified fragment of $594 \mathrm{bp}$ ) for IFN- $\gamma$-R1 encompassing a region spanning exons $1-5,5^{\prime}$-CGAAGATTCGCCTGTACAACGCA and 3'-GTCACCTCAATCTTTTCTGGAGGC (amplified fragment of $339 \mathrm{bp}$ ) for IFN- $\gamma$-R2-spanning exons $2-4$ and $5^{\prime}$-GACCTGACTGACTACCTCATGAA and 3'-CTTCATGATGGAGTTGAAGGTAG (amplified fragment of $303 \mathrm{bp}$ ) for $\beta$-actin-spanning exons $4-5$. Ten to 15 microlitres of RT-PCRs were electrophoresed with $50 \mathrm{bp}$ and $100 \mathrm{bp}$ 
markers in $2 \%$ agarose gels stained with ethidium bromide and photographed. The specific RT-PCR products were excised, purified using a QUIAEX II kit and directly sequenced with an automated detection system (ABI-PRISM 3100; PE Applied Biosystems, Foster City, CA, USA) to confirm primer-specific amplification of cDNA.

The receptor expression pattern and the mRNA levels for the five SSTR subtypes (Hoyer et al. 1995) was analysed by real-time quantitative RT-PCR (Q-PCR) in SS-C cells at the 2nd passage, using a TaqMan 5'-exonuclease assay procedure. RT-PCR was performed as previously described with the RNA solution treated with DNase I to remove trace amount of genomic DNA contamination. Specific primers and probes for five SSTR genes were designed by Proligo Primers \& Probes (Proligo LLC, Boulder, CO, USA) using the appropriate GenBank entries (sequences available on request). The homology between different subtypes was carefully examined and avoided. The lengths of all amplification products were between 60 and $186 \mathrm{bp}$. The primer specificity was tested by running a regular PCR for 40 cycles. After an initial denaturation at $94{ }^{\circ} \mathrm{C}$ for $5 \mathrm{~min}$, the samples were subjected to 40 cycles of denaturation at $94^{\circ} \mathrm{C}$ for $30 \mathrm{~s}$, annealing for $30 \mathrm{~s}$ at $60^{\circ} \mathrm{C}$ and extension for $30 \mathrm{~s}$ at $72^{\circ} \mathrm{C}$. After a final extension for $10 \mathrm{~min}$ at $72^{\circ} \mathrm{C}, 10 \mu \mathrm{l}$ aliquots of the resulting PCR products were analysed by electrophoresis on $2 \%$ agarose gels stained with ethidium bromide. The identity of the products was confirmed by direct sequencing using an ABI Prism 3100 Genetic Analyser (Applied Biosystems) according to the manufacturer's protocol. Several controls were included in the RT-PCR experiments. Since the SSTR genes are intron-less, to ascertain that no detectable genomic DNA was present in the total RNA preparation (even after DNase I treatment), the cDNA reactions were also performed without RT and amplified with each primer pair. To exclude contamination of the PCR mixtures, the reactions were also performed in the absence of DNA template in parallel with cDNA samples. As a positive control for the PCRs of the SSTR subtypes, 0.001-0.1 $\mu \mathrm{g}$ human genomic DNA was amplified in parallel with cDNA samples. Q-PCR was performed for all five SSTRs, even if no expression of the SSTR3 and 5 subtypes could be detected in the cells we investigated by RTPCR. In each experiment, standard curves for each primer set were included. Known amounts of dilutions of each PCR product were amplified in duplicate together with the unknown cDNA sample. A standard curve was constructed by plotting the threshold-cycle (Ct) vs the logarithm of the starting quantity (from
$3 \times 10$ to $3 \times 10^{10}$ molecules). By interpolation on these standard curves of the measured $\mathrm{Ct}$ of the unknown cDNA samples, the starting amounts in the cDNA sample were determined in duplicate. Reactions conditions were optimized until the s.D. of duplicate determinations of the $\mathrm{Ct}$ of standard curve samples was $<3 \%$. Levels of SSTRs genes in somatostatinoma cells are expressed as molecules of specific mRNA/ $\mu \mathrm{g}$ total RNA and reported as means \pm s.D. The primers and probe for SSTR2 mRNA quantification to use with the ABI Prism 7700 Sequence Detection System were selected by the proprietary software Primer Express, on the sequence NM 001050 (GeneBank). The forward primer corresponds to the region from base 448 to base 466 (sequence 5'-TCGGCCAAGTGGAGGAGAC $-3^{\prime}$ ). The reverse primer corresponds to the region from base 491 to base 510 (5'AGAGACTCCCCACACAGCCA-3 ${ }^{\prime}$ ). The internal oligonucleotide probe (CCGGACGG-CCAAGATGATCACC) is $5^{\prime}$-end FAM-labelled and $3^{\prime}$-end TAMRA-labelled. Four thousand nanograms of total RNA were reverse-transcribed by random examers, following the classic reverse transcription PerkinElmer protocol. The PCR mixture contains primers (200 $\mathrm{mM}$ each) and $200 \mathrm{nM}$ of the TaqMan probe, with a final volume of $25 \mu \mathrm{l}$. Amplification and detection are performed with the ABI Prism 7700 Sequence Detection System with the following profile: one step at $50^{\circ} \mathrm{C}$ for $2 \mathrm{~min}$, one step at $95^{\circ} \mathrm{C}$ for $10 \mathrm{~min}$, and 40 cycles at $95^{\circ} \mathrm{C}$ for $30 \mathrm{~s}$, and $60^{\circ} \mathrm{C}$ for $1 \mathrm{~min}$. The amount of product was measured by interpolation from a standard curve of $\mathrm{Ct}$ values generated from known initial concentrations of RNA extracted from the neuroblastoma cell line $\mathrm{CHP} 4 \mathrm{O} 4$, which overexpresses SSTR2 mRNA. One microgram of CHP4O 4 RNA was reverse transcribed and cDNA was then serially diluted to obtain five standard solutions to be used in the PCR to generate the reference curve (Iguchi et al. 1990), with the first point corresponding to $2 \times 10^{9}$ molecules of SSTR $2 \mathrm{mRNA} / \mu \mathrm{g}$ total RNA.

\section{Whole-cell binding assay}

SS-C cells were evaluated for the capability to bind to SST. SS-C cells at the 2nd passage were plated into four replicate wells of a 96-well polypropylene plates and grown to confluence. The medium was aspirated, and the cells were washed once with $50 \mathrm{mM}$ Tris- $\mathrm{HCl}$, $\mathrm{pH} 7.8$, containing $1 \mathrm{mM}$ EGTA, $5 \mathrm{mM} \mathrm{MgCl}_{2}$ and $0.1 \%$ BSA (buffer A) and maintained in buffer A at room temperature for $30 \mathrm{~min}$. This buffer was aspirated and replaced with buffer B (buffer A containing $1 \mathrm{mg} / \mathrm{ml}$ bacitracin). Test compounds were examined 
over a range of concentrations from 0.01 to $10000 \mathrm{nM}$ at room temperature for $45 \mathrm{~min}$ in a final volume of $200 \mu \mathrm{l}$ using $0.1 \mathrm{nM} 3-\left[{ }^{125} \mathrm{I}\right]$ iodotyrosyl ${ }^{25}$-somatostatin-28 $\left(\mathrm{Leu}^{8}{ }^{8} \mathrm{D}-\mathrm{Trp}^{22}, \mathrm{Tyr}^{25}\right)$ ligand. The cells were washed three times with buffer A and then air-dried. The cells were solubilized by the addition of $25 \mu 11 \%$ SDS in $0.1 \mathrm{M} \mathrm{NaOH}$ to each well and then $200 \mu \mathrm{l}$ MicroScint-40 scintillation fluid. Radioactivity was determined in a scintillation counter. $K_{\mathrm{i}}$ values were calculated with the Cheng-Prussof equation (Cheng \& Prussof 1973). $K_{\mathrm{d}}$ values for 3-[ $\left.{ }^{125} \mathrm{I}\right]$ iodotyrosyl ${ }^{25}$ somatostatin-28 $\left(\mathrm{Leu}^{8}, \mathrm{D}-\mathrm{Trp}^{22}, \mathrm{Tyr}^{25}\right)$ were determined from Scatchard plots of the saturation binding curves.

\section{Cell growth and viability}

Cell growth was measured by cell counting. For this purpose $3 \mathrm{rd}$ passage SS-C cells were plated at a density of $3 \times 10^{5}$ cells $/ 35 \mathrm{~mm}$ dish under the indicated experimental conditions. After $96 \mathrm{~h}$ cells were detached with trypsin solution and the cell number was evaluated by a haemocytometer.

Cell viability was assessed by Trypan blue dye uptake/exclusion assay in SS-C cells after short-term exposure to various agents. Briefly, cells were exposed to a given stimulus for $30 \mathrm{~min}$ and then detached with trypsin solution. One drop of cell suspension was added to one drop of Trypan blue dye solution $(0.3 \%$ in PBS) and blue stained vs unstained cells were counted and expressed as a percentage.

\section{Measurement of telomerase activity}

Telomerase activity in intact 2 nd passage SS-C cells was measured using a modified non-radioactive telomerase repeat amplification protocol (Naasani et al. 1998, Falchetti et al. 1999). Telomere length was measured by a solution hybridization-based method (Gan et al. 2001). In brief, genomic DNA was isolated and $10 \mu \mathrm{g}$ DNA were digested at $37^{\circ} \mathrm{C}$ overnight with 10 units each of $\mathrm{HinfI} / \mathrm{CpoI} / \mathrm{HeaIII}$. The probe (TTAGGG) $)_{4}$ was labelled with $\left[\gamma_{-}{ }^{32} \mathrm{P}\right] \mathrm{ATP}$ with polynucleotide T4 kinase. Three nanograms of the probe were added to $2.5 \mu \mathrm{g}$ DNA solution. After denaturation at $98^{\circ} \mathrm{C}$ for $5 \mathrm{~min}$, hybridization was performed at $55^{\circ} \mathrm{C}$ overnight. The resulting samples were electrophoresed on $0.7 \%$ agarose gel. After drying under vacuum without heating, the gel was exposed to a phosphorimage screen, and the results were analysed using the area-under-the curve method for the ImageQuant software. The point representing 50\% of the area-under-the-curve was the mean telomere length. Genomic DNA was extracted from homogenized human somatostatinoma cultured cells after different times of exposure to the telomerase inhibitor $3^{\prime}$-azido-3'deoxythymidine (AZT). Human malignant mammary cancer (MCF-7) cells (ATCC; catalogue number HTB-22) were used as positive control (Soule \& McGrath 1986, Kim et al. 1994). SS-C cells were treated with $100 \mu \mathrm{M}$ AZT for different times and total cells were collected and analysed for the mean telomere length.

Human 2nd passage SS-C cells were also evaluated for mutations of the TP53 gene in exons 5-8. The TP53 gene mutation screening kit was used to detect the presence of any kind of mutation in exons 5, 6, 7 and 8 of TP53 gene, according to the manufacturer's instructions. Briefly $100 \mathrm{ng}$ DNA were used in PCRs with five different pairs of primers (supplied in the kit) designed to span exons 5-8. $\mathrm{MgCl}_{2}$ concentrations were $1.5 \mathrm{mM}$ for primers $\mathrm{A}-\mathrm{C}$ and $\mathrm{E}$ and $2 \mathrm{mM}$ for primer $\mathrm{D}$; annealing temperatures were $55^{\circ} \mathrm{C}$ for primers $\mathrm{A}$ and $\mathrm{E}$ and $60^{\circ} \mathrm{C}$ for primers $\mathrm{B}-\mathrm{D}$ and PCR cycle steps were $2 \mathrm{~min}$ at $95^{\circ} \mathrm{C}, 40$ cycles $35 \mathrm{~s}$ at $94^{\circ} \mathrm{C}, 40 \mathrm{~s}$ at the relative annealing temperature, $40 \mathrm{~s}$ at $72{ }^{\circ} \mathrm{C}$ and a final extension step at $72{ }^{\circ} \mathrm{C}$. PCR products were analysed on a $2 \%$ agarose gel for specificity of reaction. Two microlitres of PCR product were added with $6 \mu \mathrm{l}$ denaturing loading buffer $(95 \% \mathrm{v} / \mathrm{v}$ formamide, $10 \mathrm{mM}$ EDTA, $0.1 \%$ basic fuchsin, $0.01 \%$ bromophenol blue), denatured at $95{ }^{\circ} \mathrm{C}$ for $5 \mathrm{~min}$ and loaded on a $12 \%$ acrylamide gel in TBE. Running conditions were $5 \mathrm{~mA}$ for $14-18 \mathrm{~h}$ in TBE $1 \times$ at $20^{\circ} \mathrm{C}$ through water recycling. At the end of the run the gels were silver stained: $10 \%$ ethanol for $5 \mathrm{~min}, 1 \%$ nitric acid for $3 \mathrm{~min}, 2 \mathrm{mM}$ silver nitrate for $20 \mathrm{~min}$, three washes with $0.019 \%$ formaldehyde in sodium carbonate $0.28 \mathrm{M}, 10 \%$ acetic acid for $2 \mathrm{~min}$.

\section{Flow cytometry}

Antibody staining was performed on $1 \times 10^{6} 4$ th passage SS-C cells for the conjugated primary antibody. Apoptosis was assayed with propidium iodide/ annexin V staining. For propidium iodide/annexin VFITC staining of apoptosis, cells were washed with annexin V FACS buffer (HBSS buffer with calcium, magnesium, sodium azide, and $0.5 \%$ BSA) and incubated on ice with 1:30 dilution of annexin VFITC for $30 \mathrm{~min}$ and washed in FACS buffer. Prior to FACS analysis, propidium iodide at $5 \mu \mathrm{g} / \mathrm{ml}$ was added to the cells and gently mixed. Stained cells were immediately analysed by FACS. 

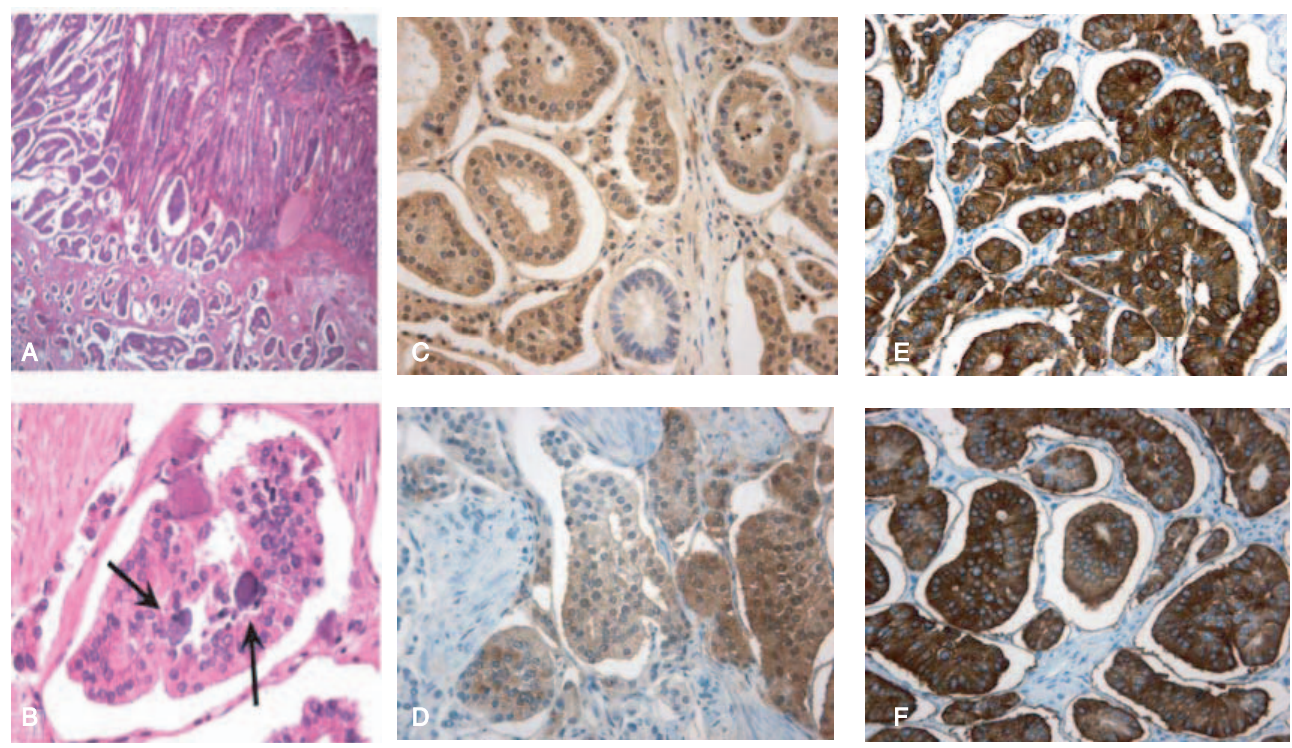

Figure 1 Microscopic view of the jejunal tumour with a vague acinar to ribbon-like pattern $(A)$ (original magnification $\times 50$ ). High-power view of somatostatinoma revealing scattered psammoma bodies (B) (original magnification $\times 200$ ). Jejunal somatostatinoma tissue exhibited strong diffuse staining with somatostatin (C), NSE (D), CgA (E) and synaptophysin (F) (original magnification $\times 150$ for $\mathrm{C}$ and $\times 100$ for $\mathrm{D}-\mathrm{F}$ ).

\section{Caspase activity}

Apoptosis of 3rd passage SS-C cells was measured using a caspase-3 colourimetric assay with spectrophotometric quantification at $405 \mathrm{~nm}$. Stimuli were added to the cells at the indicated concentrations and compared with control cultures (SS-C cells not exposed to any stimulus). Apoptosis was assessed following the manufacturer's protocol in cells cultured in six-well plates over a $24 \mathrm{~h}$ period. Cell protein content was assessed using a detergent-compatible protein assay reagent, based on the Lowry procedure (Lowry et al. 1951) and lyophilized bovine plasma gamma globulin was used as standard.

\section{Statistics}

All the experiments were carried out in triplicate and data expressed as means \pm s.D. of triplicate experimental points. Statistical differences were analysed using one-way ANOVA and significance was evaluated by standard Chi-square test by using Statistica 5.1 (Statsoft Inc., Tulsa, OK).

\section{Results}

\section{Patient's clinical features}

The high circulating levels of SST $(3233 \mathrm{pg} / \mathrm{ml}$; normal value: $\leq 37 \mathrm{pg} / \mathrm{ml})$ and NSE $(17.7 \mathrm{ng} / \mathrm{ml}$; normal value: $0-13 \mathrm{ng} / \mathrm{ml}$ ) confirmed the presence of metabolic somatostatinoma. A genetic test for MEN1 gene mutations was negative. CT evidenced the presence of hepatic lesions. An MRI demonstrated that the hepatic results were compatible with secondary lesions. Pancreatic echoendoscopy did not evidence lesions of the pancreatic, gastric and duodenal levels. An Octreoscan (scanning agent was ${ }^{111}$ Indium-diethylenetriamine pentaacetic acid-octreotide) $\left[{ }^{111}\right.$ In-DPTA octreotide] was negative, probably due to a saturation of the receptor sites by the high levels of circulating SST.

\section{Pathology of tumour tissues}

Microscopically, the tumour cells, small to mediumsized round cells with clear large cytoplasm, were arranged in a trabecular or ribbon pattern separated by delicate fibrovascular stroma. Scattered psammoma bodies were identified within the tumour (Fig. 1). Immunohistochemically, the cytoplasm of the neoplastic cells from the primary jejunal lesion and from the liver metastases (data not shown) was strongly positive for SST, CgA, NSE and synaptophysin (Fig. 1). Tumour cells showed no positive staining for insulin, glucagon, gastrin and PP.

\section{Cell cultures}

Cells obtained from the primary tumour and from one of the liver metastases were cultured in growth medium 

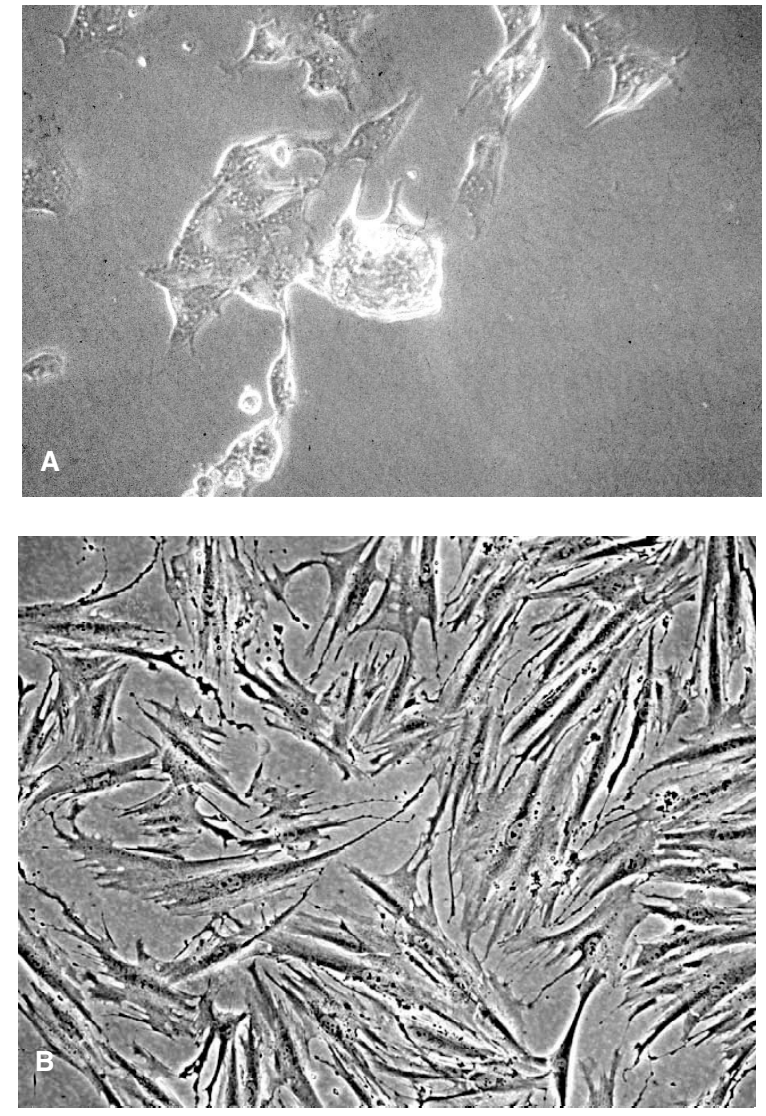

Figure 2 Contrast phase image of (A) primary cultures of somatostatinoma (original magnification $\times 200$ ) and of subconfluent SS-C cells at the 3rd passage (original magnification $\times 100)$.

and analysed at different times for morphological, growth and differentiative properties. Cell cultures obtained from the liver metastasis were not successful, as they did not adhere to the culture dish. Conversely, primary cultures from the primary somatostatinoma tissue were characterized by clusters of epithelial-like cells from which elongated cells originated and colonized the culture dish (Fig. 2). These cells, obtained in very large quantity out of the primary tumour and indicated as SS-C cells, grew as a firmly attached monolayer, showing a homogeneous phenotype with a neuronal-like appearance (Fig. 2). Weekly passage of SS-C cells made it possible to obtain well-characterized cultures to be frozen and used for functional and growth studies. The population doubling-time of SS-C cells calculated from the growth curve ranged from 3.2 days at the 1st passage to 4 days at the 5th serial passage and to 5.8 at the 12th serial passage. The chromosome counts of 100 metaphase
Table 2 Basal secretion rates of SST, other gastroenteropancreatic hormones, $\mathrm{CgA}$, and NSE by SS-C cells at 7 days (1st passage), 40 days (5th passage) and 60 days (8th passage) in culture

\begin{tabular}{lccc}
\hline & \multicolumn{3}{c}{ Basal secretion ${ }^{\text {a }}$ (pg/10 $\mathbf{5}^{\text {cells/h) }}$} \\
\cline { 2 - 4 } Product & $\begin{array}{c}\text { 7 days } \\
\text { (1st passage) }\end{array}$ & $\begin{array}{c}40 \text { days } \\
\text { (5th passage) }\end{array}$ & $\begin{array}{c}60 \text { days } \\
\text { (8th passage) }\end{array}$ \\
\hline SST & $3723 \pm 440$ & $2825 \pm 360$ & $1641 \pm 318$ \\
CgA & $40450 \pm 813$ & $28511 \pm 2077$ & $18640 \pm 2880$ \\
Glucagon & $25 \pm 2$ & $15 \pm 3$ & N.D. \\
CGRP & $18 \pm 3$ & N.D. & N.D. \\
Calcitonin & $8 \pm 0.5$ & N.D. & N.D. \\
Insulin & N.D. & N.D. & N.D. \\
C-Peptide & N.D. & N.D. & N.D. \\
Gastrin & N.D. & N.D. & N.D. \\
PP & N.D. & N.D. & N.D. \\
GIP & N.D. & N.D. & N.D. \\
CK & N.D. & N.D. & N.D. \\
VIP & N.D. & N.D. & N.D. \\
Histamine & N.D. & N.D. & N.D. \\
Substance P & N.D. & N.D. & N.D. \\
NSE & N.D. & N.D. & N.D. \\
\hline
\end{tabular}

${ }^{a}$ Means \pm S.D. of three replicate dishes in two independent experiments.

${ }^{\mathrm{b}}$ N.D., not detectable.

cells revealed the modal peak to be 46 , with only few cells showing some deviation from this diploid mode. SS-C cells did not show changes in morphological characteristics up to the 12th serial transfer, with major signs of senescence observed afterwards. For this reason in this study SS-C cells were used between the primary culture and the 5 th passage.

Confluent cultures of SS-C cells were tested for hormonal production. Similar to what was observed in tissue immunohistochemistry, SS-C cells at the 1st passage ( 7 days), at the 5 th passage ( 40 days), and at the 8 th passage (60 days) exhibited the ability to secrete SST into the culture medium (Table 2). The molarities of SST in the culture medium reached a maximum of $50 \mathrm{nM}$. High amounts of $\mathrm{CgA}$ were released into the culture medium by SS-C cells at the 1st passage, with half of the values found after 8 passages (Table 2). Measurable levels of glucagon, CGRP and calcitonin were detected in 1st passage SS-C cells, while this characteristic was lost in long-term cultures (Table 2). No release of insulin, C-peptide, gastrin, PP, GIP, CK, VIP, histamine, substance $P$, and NSE was detected in culture media of primary cultures and long-term cultures of SS-C cells. None of the neuropeptides tested was measurable in the Coon's modified Ham's F12 medium used for the incubation. The addition of 
known concentrations of SST to the culture medium allowed $92 \%$ recovery.

As shown in Fig. 3, after $1 \mathrm{~h}$ incubation, $50 \mathrm{mM} \mathrm{K}^{+}$ caused a 6-fold increase of SST secretion by SS-C cells at the 1st passage. Significant stimulation (8-fold) of SST secretion was seen in the presence of $10 \mathrm{mM}$ theophylline (Fig. 3). Octreotide $(1 \mu \mathrm{M})$ was able to decrease by $58 \%$ the release of SST from 1st passage SS-C cells (Fig. 3). Basal values of SST release in the controls were $4100 \pm 640 \mathrm{pg} / 10^{5}$ cells.

\section{Characterization of expression of SSTRs, IFN- $\gamma$ and IFN- $\gamma$-Rs}

In the qualitative analysis of SSTRs, IFN- $\gamma$, IFN- $\gamma$-R 1 and IFN- $\gamma$-R2 expression no PCR products were detected in samples without RT or in the absence of cDNA template. No expression of the SSTR3 and 5 subtypes could be detected in SS-C cells at the 2 nd passage by RT-PCR (Fig. 4A). Q-PCR performed for

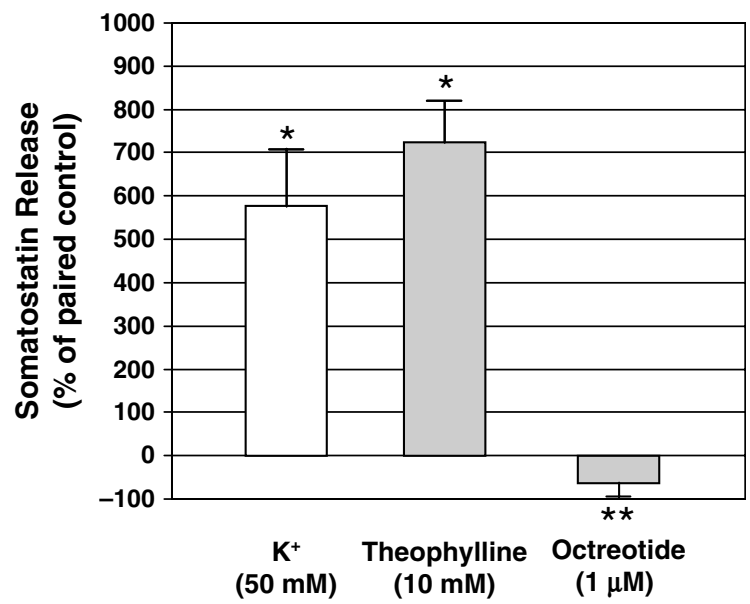

Figure 3 Effect of $50 \mathrm{mM} \mathrm{K}^{+}, 10 \mathrm{mM}$ theophylline and $1 \mu \mathrm{M}$ octreotide on SST secretion by SS-C cells at the 1st passage. SS-C cells were incubated in triplicate for $1 \mathrm{~h}$ in the presence of the different stimuli. Columns, means \pm s.D. of triplicate samples. ${ }^{\star} P<0.05$ and ${ }^{\star \star} P<0.01$ (vs untreated cells).
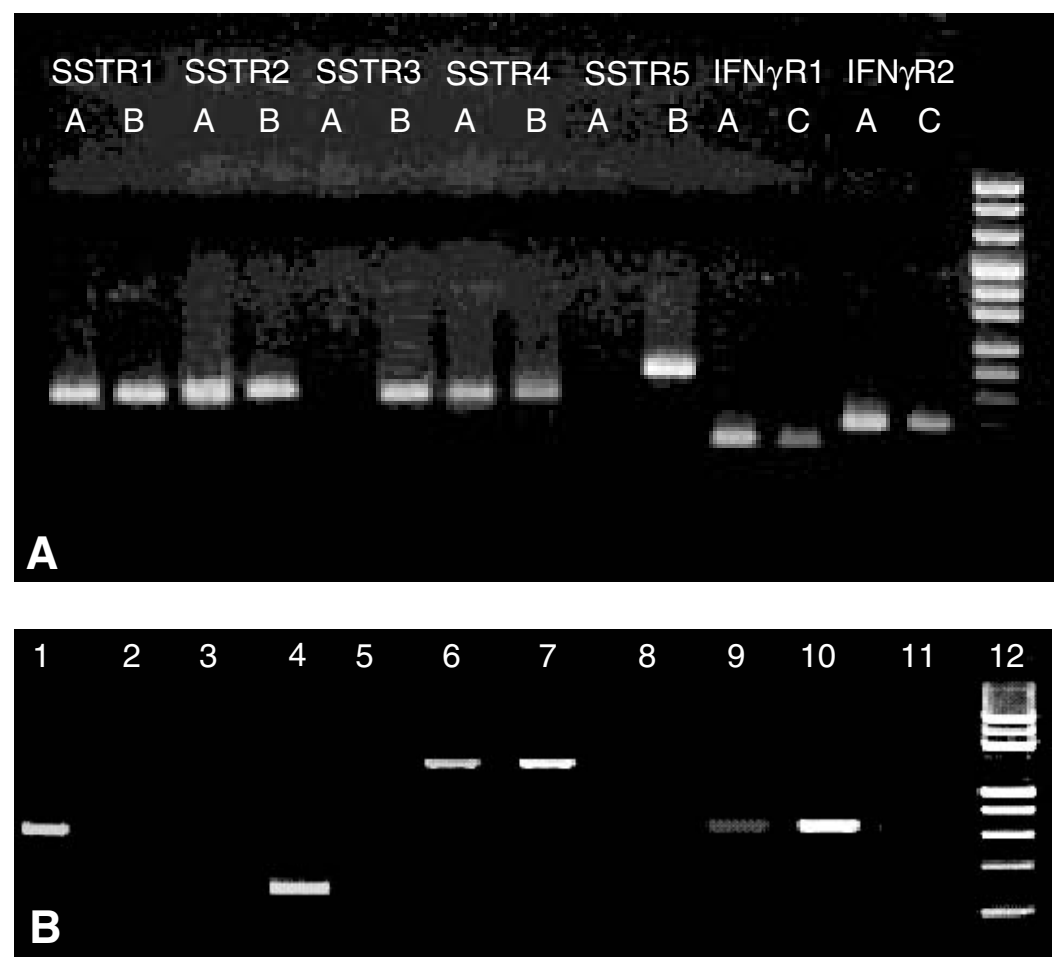

Figure 4 (A) Expression of mRNA for SSTR subtypes and IFN- $\gamma$, IFN- $\gamma$ R1 and IFN- $\gamma$ R2 in SS-C cells. Real-time RT-PCR efficiencies confirmed by a regular RT-PCR. Total RNA was extracted from SS-C cells at the 2nd passage. PCR products of SSTR 1-5 and IFN $\gamma$ R-1 and 2 were separated on $2 \%$ agarose gel and stained with ethidium bromide. Molecular weight marker is DNA Molecular Weight Marker VIII (Roche); 'A': somatostatinoma sample; 'B': genomic DNA as positive control; ' $C$ ': T lymphocytes as positive control. RT-PCR analysis of each SSTR was performed at least twice with identical results. (B) Expression of mRNA in SS-C cells by conventional RT-PCR using primer set shown in Table 1. SS-C cell $\beta$-actin is shown in lane 1 ; lanes 2, 5 and 8 represent negative controls (PCR without template). In lanes 3,6 and 9 , IFN- $\gamma$, IFN- $\gamma-\mathrm{R} 1$ and IFN- $\gamma-\mathrm{R} 2$ are respectively depicted. Lanes 4,7 and 10 contain positive controls (normal human T lymphocytes). In lane 12 a $100 \mathrm{bp}$ DNA ladder (size range 100-1000 bp) is shown. 


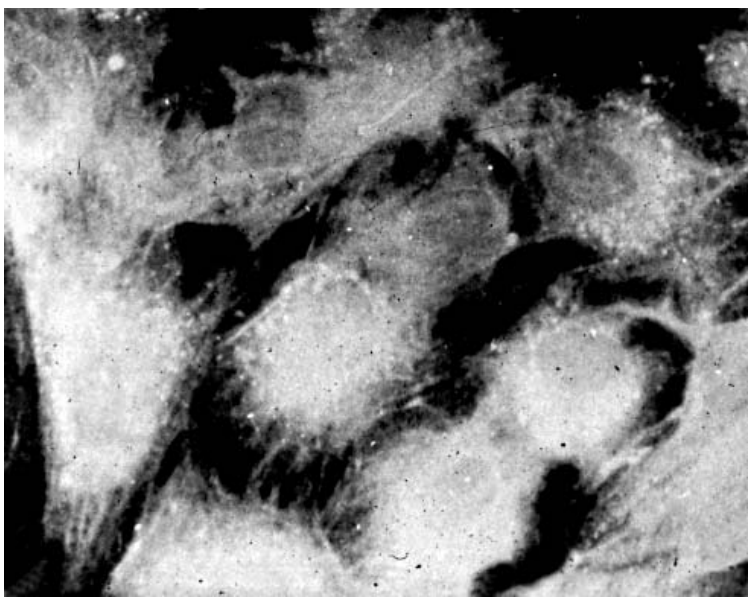

Figure 5 Immunocytochemical localization of SSTR2 in SS-C cells at the 4th passage. A specific SSTR2 antibody evidenced a positive diffuse cytoplasmic staining. Original magnification $\times 100$.

all five SSTRs confirmed these findings and no $\mathrm{Ct}$ was observed for SSTR3 and 5. Expression levels of SSTR1, 2 and 4 genes in SS-C cells expressed as molecules of specific mRNA/ $\mu \mathrm{g}$ total RNA reported as mean \pm S.D. were: SSTR1, $(2.19 \pm 0.05) \times 10^{12}$; SSTR2, $(1.39 \pm 0.04) \times 10^{8}$; and SSTR4, $(7.82 \pm 0.17) \times 10^{6}$. SS$\mathrm{C}$ cells at the 2nd passage showed SSTR2 gene expression, with a mean value of $3.48 \times 10^{6}$ molecules of SSTR 2 mRNA/25 ng total RNA, corresponding to $1.39 \times 10^{8}$ molecules of SSTR $2 \mathrm{mRNA} / \mu \mathrm{g}$ total RNA (data not shown).

RT-PCR analysis of IFN- $\gamma$, IFN $\gamma$-R1, IFN $\gamma$-R2 and $\beta$-actin (housekeeping gene) mRNA in 2nd passage SS$\mathrm{C}$ cells is shown in Fig. 4B. A higher expression of both IFN- $\gamma$-R 1 and -R2 mRNAs was observed in SS-C cells compared with the positive control (normal human $\mathrm{T}$ lymphocytes), whereas IFN- $\gamma$ was not expressed in SS-C cells (Fig. 4B).

Immunocytochemical localization of SSTR2 in SS-C cells at the 4th passage showed a diffuse cytoplasmic staining (Fig. 5). No labelling was observed in the absence of the primary antibody and in human skin fibroblasts (data not shown). In SS-C cells at the 2nd passage the apparent dissociation constants for SST-28 and octreotide were 0.4 and $0.7 \mathrm{nM}$ respectively (data not shown).

\section{Telomere length and modulation by a telomerase inhibitor}

Human 2nd passage SS-C cells showed a telomere length of $1588 \pm 179 \mathrm{bp}$, with no mutations in exons 5-8 of the TP53 gene (data not shown). The telomerase inhibitor, AZT, at a concentration of $0.1 \mathrm{mM}$ inhibited in a time-dependent manner telomerase activity in 2nd passage SS-C cells, with maximal effect $(49 \pm 9 \%)$ at $72 \mathrm{~h}$ (data not shown).

\section{Antiproliferative activity of SST-28, octreotide, IFN- $\gamma$ and AZT on human SS-C cells}

Having established functional SST-28 and IFN- $\gamma$ receptors and AZT signalling, we evaluated the effects of SST-28, octreotide, IFN- $\gamma$ and AZT on growth of 3rd passage SS-C cells cultured in medium containing $10 \%$ FCS. SST-28 and octreotide inhibited SS-C cell proliferation in a dose-dependent manner with maximal effect at micromolar doses (Fig. 6). Similarly, the antiproliferative action of IFN- $\gamma$ was dosedependent, with a maximal inhibition to $25 \pm 4.2 \%$ of control observed at a concentration of $500 \mathrm{IU} / \mathrm{ml}$ (Fig. 6). AZT inhibited SS-C cell proliferation at a range of concentrations from 0.01 to $1.0 \mathrm{mM}$, with maximal effect at $1.0 \mathrm{mM}$ (Fig. 6). In the same experimental conditions the combined inhibitory action of $1 \mu \mathrm{M}$ SST-28 with $500 \mathrm{IU} / \mathrm{ml}$ IFN- $\gamma$ and $1 \mathrm{mM}$ AZT was additive, while octreotide was inert in the presence of the SST-28 (Fig. 7). None of the stimuli were able to affect SS-C cell viability as assessed by the Trypan blue exclusion test after 30 min exposure to the stimuli (data not shown).

\section{SST-28, octreotide, IFN- $\gamma$ and AZT induce apoptosis of SS-C cells}

SS-C cells at the 4 th passage were cultured for $48 \mathrm{~h}$ in the presence of increasing concentrations of SST-28 $(0.001-1.0 \mu \mathrm{M})$, of octreotide $(0.001-1.0 \mu \mathrm{M})$, of IFN- $\gamma$ $(0.5-500 \mathrm{IU} / \mathrm{ml})$ and of AZT $(0.001-1.0 \mathrm{mM})$ and then apoptosis was measured by annexin $\mathrm{V}$ flow cytometry. All three substances induced apoptosis in a dosedependent manner in SS-C cells (Fig. 8).

Twenty-four hour exposure to SST-28 and octreotide at $1 \mu \mathrm{M}$ increased apoptosis in the 4 th passage SS-C cells as determined by caspase- 3 activity, by respectively $580 \%$ and $567 \%$ compared with control cells $(P<0.001)$ (Table 3$)$. Caspase-3 activity was also significantly increased in cells exposed to IFN- $\gamma$ $(500 \mathrm{IU} / \mathrm{ml})$ and AZT $(1 \mathrm{mM})$ (Table 3).

\section{Discussion}

Somatostatinoma is a rare disorder whose diagnosis at a metastatic stage is not infrequent and the treatment with non-surgical anticancer therapies is doubtful. Moreover, the low percentage of proliferating tumour 

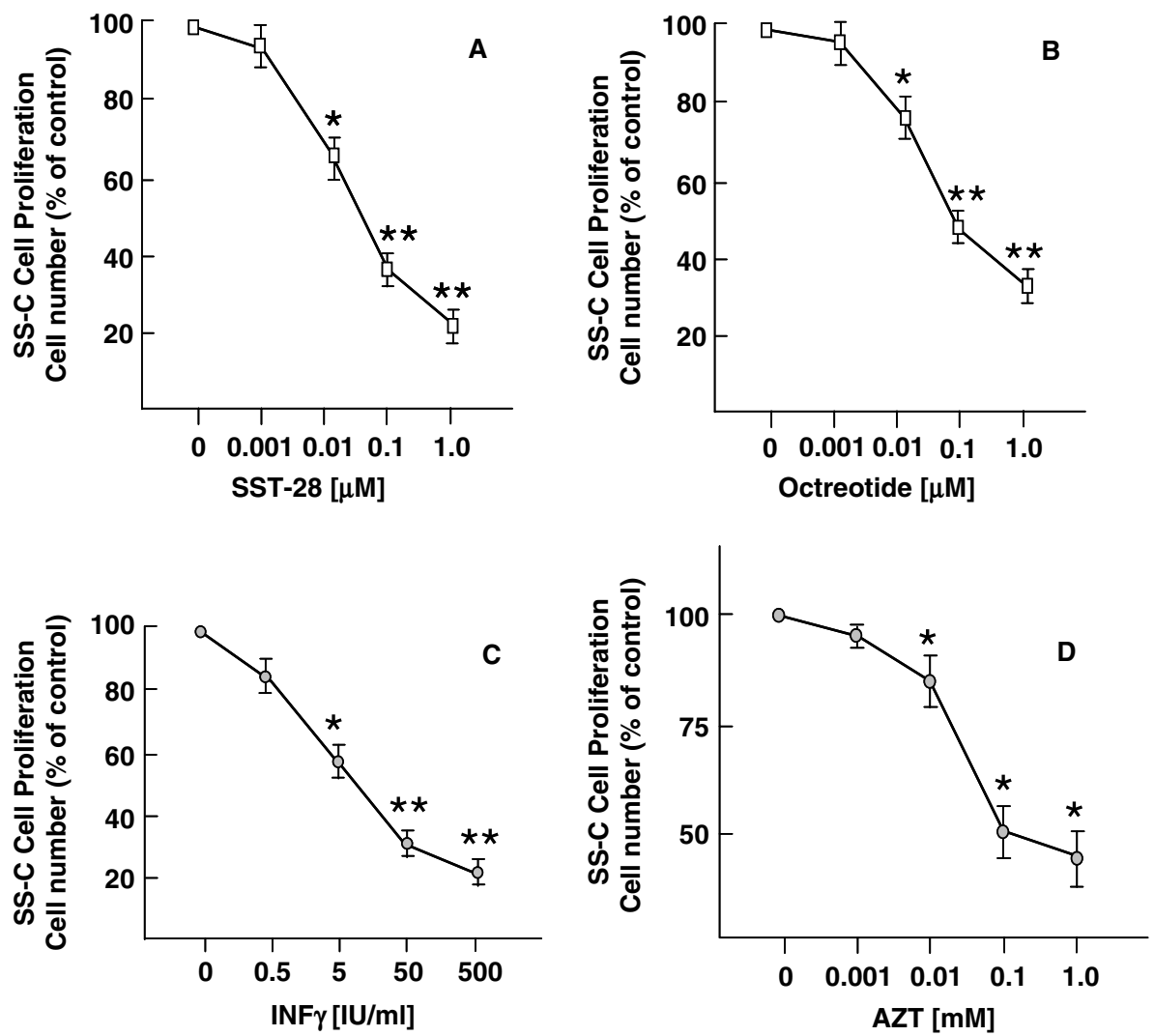

Figure 6 SST-28 $(1 \mu \mathrm{M})$, octreotide $(1 \mu \mathrm{M})$, IFN- $\gamma(500 \mathrm{IU} / \mathrm{ml})$ and AZT $(1 \mathrm{mM})$ inhibited proliferation of 2nd passage SS-C cells cultured in the presence of $10 \%$ FCS. Results are means \pm s.D. of three experimental points. ${ }^{*} P<0.05$ and ${ }^{* *} P<0.01$ (vs untreated cells).



Figure 7 SST-28 $(1 \mu \mathrm{M})$, octreotide $(1 \mu \mathrm{M})$, IFN- $\gamma(500 \mathrm{IU} / \mathrm{ml})$ and AZT $(1 \mathrm{mM})$ inhibited proliferation of 3rd passage SS-C cells cultured in the presence of $10 \%$ FCS. The combined presence of SST-28, IFN- $\gamma$ and AZT caused an additive effect, while octreotide was inert in the presence of SST-28. Results are means \pm S.D. of three experimental points. ${ }^{\star} P<0.05$ and ${ }^{\star \star} P<0.01$ (vs untreated cells).

cells limits the use of conventional chemotherapy, while the need for therapy rather arises from the presence of an SST hypersecretion syndrome.
Currently, available systemic treatment options for somatostatinoma suffer from failure to achieve convincing tumour regression. For all these reasons the 

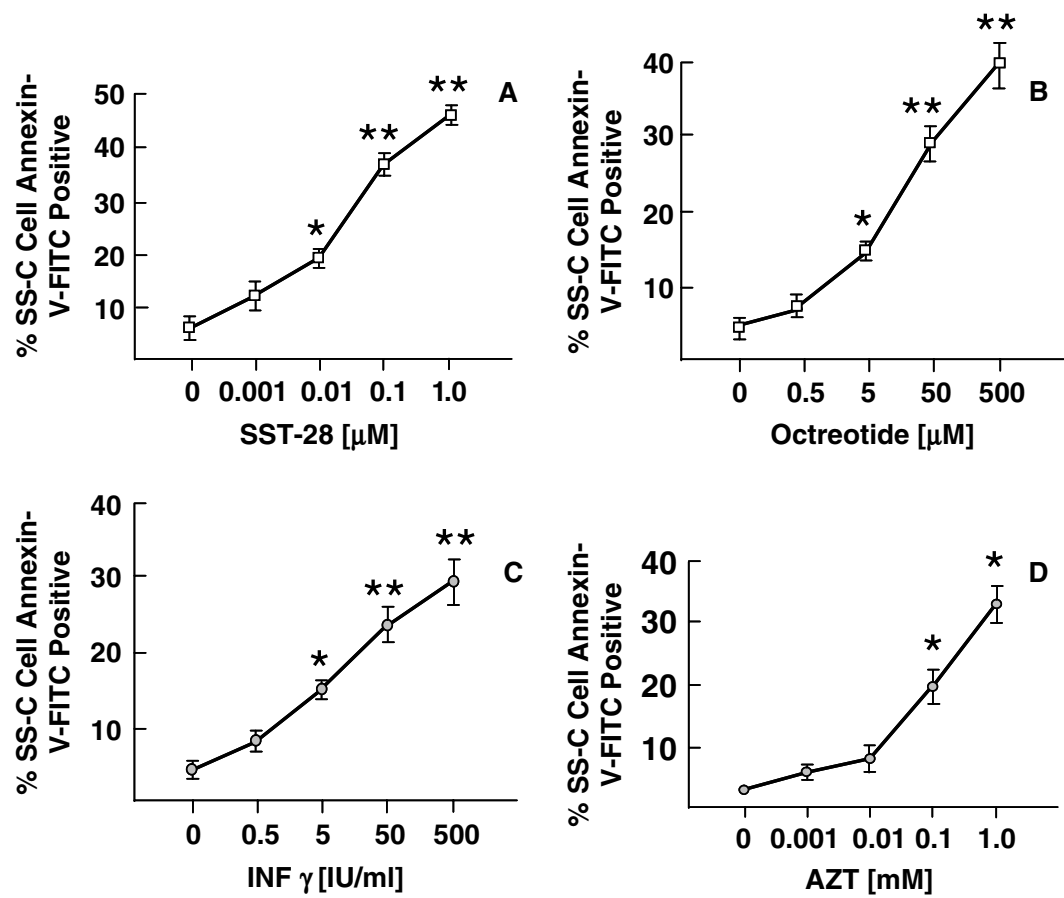

Figure 8 SST-28 (A), octreotide (B), IFN- $\gamma(C)$ and AZT (D) induced apoptosis in a dose-dependent manner in 4th passage SS-C cells, as measured by annexin $V$ flow cytometry. Results are means \pm s.D. of three experimental points. ${ }^{\star} P<0.05$ and ${ }^{* *} P<0.01$ (vs untreated cells).

Table 3 Effect of SST-28, octreotide, IFN- $\gamma$ and AZT on caspase-3 activity (optical density at $405 \mathrm{~nm} / \mathrm{mg}$ protein) in SS-C cell cultures at the 4 th passage

\begin{tabular}{lcc}
\hline & $\begin{array}{c}\text { Caspase-3 } \\
\text { activity* (OD/mg protein) }\end{array}$ & $\boldsymbol{P}$ value \\
\hline Control & $0.19 \pm 0.01$ & - \\
SST-28 $(1 \mu \mathrm{M})$ & $1.10 \pm 0.12$ & $<0.001$ \\
Octreotide $(1 \mu \mathrm{M})$ & $1.07 \pm 0.09$ & $<0.001$ \\
IFN $\gamma(500 \mathrm{IU} / \mathrm{ml})$ & $0.61 \pm 0.07$ & $<0.01$ \\
AZT $(1 \mathrm{mM})$ & $0.78 \pm 0.09$ & $<0.01$ \\
\hline
\end{tabular}

${ }^{*}$ Results are expressed as means \pm s.D. of six experimental points.

development of well-characterized antiproliferative strategies appears mandatory.

The present report describes the long-term culture of a human cell line, SS-C, from a patient diagnosed as having somatostatinoma of the jejunum. The characteristics of SS-C cells are high production of SST and of $\mathrm{CgA}$, a neuronal-like morphology and growth as a monolayer. SST and CgA expression were evidenced also in the somatostatinoma tissue, that, differently from cultured cells also expressed NSE. SS-C cells also responded to depolarizing and cAMP-dependent stimuli, as shown in a previous model of human
SST-secreting cells in continuous culture, the QGP-1 cell line (Detjen et al. 2002). The latter cell model was characterized by the production of SST, PP and CEA (Detjen et al. 2002). However, the tumour from which QGP-1 cells were derived was not indicated as a somatostatinoma, but as a "neuroendocrinepancreatic tumour' (Detjen et al. 2002). In addition, in SS-C cells the SST analogue, octreotide, was able to significantly inhibit SST release in culture. The rarity of somatostatinoma cell cultures makes the SS-C cell line a unique model for evaluation of both molecular marker expression and in vitro effects of molecules active on expressed targets. Here we provide evidence for control of human SS-C cell proliferation via growth inhibition and apoptotic cell death by SST-28, octreotide, IFN- $\gamma$ and an inhibitor of telomerase activity, AZT.

SS-C cells expressed mRNA for type 1, 2 and 4 SSTR, confirming that multiple SSTR subtypes are coexpressed in the same cell. The expression of SSTR subtypes in SS-C cells diverges from the pattern described for somatostatinoma tissues in a previous report of cases (Papotti et al. 2002). Such a difference can be interpreted as a cell-specific phenotype, as supported by data concerning the cell-specific localization of the SSTR subtypes (Mezey et al. 1998). However, the expression of type 2 SSTR and its 
cytosolic distribution are in agreement with immunohistochemical results on somatostatinoma tumour tissues (Reubi et al. 2000, Papotti et al. 2002, Liu et al. 2003). The expression of SSTRs in human somatostatinoma cells represents a logical basis for the use of native SST and/or its analogues in the control of differentiative and proliferative features of this tumour.

The use of the pan-receptor agonist SST-28 showed that the natural hormone inhibits proliferation of growing human SS-C cells, while inducing cellular apoptosis. Interestingly, the maximal in vitro effect of SST-28 was obtained at doses 10 - to 100 -fold higher than the concentrations of the hormone released into the culture medium. The well-characterized antiproliferative activity of SST-28 on other endocrine tumours (Arnold et al. 1996, Florio et al. 2003) opens interesting possibilities in the medical treatment of this rare endocrine malignancy. Natural SST-28 is not suitable for long-term clinical application, but in clinical practice SST analogues that show a preferential affinity for SSTR2 and SSTR5, with medium affinity to SSTR3 (octreotide and lanreotide) are available (Yang et al. 1998). Previous in vivo studies showed that Octreoscan-positive somatostatinomas respond to octreotide therapy with decrease in the plasma levels of SST (Angeletti et al. 1998). As for other targets also in somatostatinoma tissue octreotide exerted its biological actions by inhibiting both hormone secretion and cell proliferation, and via induction of apoptosis. Interestingly, as the binding affinity and biological actions of SST-28 and octreotide are superimposable in SS-C cells, the SSTR2 molecules appear responsible for their biological effects on this cell model, including apoptosis signalling. Our results add new information on the in vitro direct effects of SST on somatostatinoma cells, opening the possibility of the need for testing somatostatinoma tissue for expression of SSTRs even in Octreoscan-negative patients.

SS-C cells also express IFN- $\gamma$ receptors. IFN- $\gamma$ is a cytokine which also acts as a key regulator of proliferation, differentiation and survival, mainly via the inhibition of G1 or S-phase cell cycle progression (Platanias \& Fish 1999, Sangfelt et al. 2000) and the induction of apoptosis (Tamura et al. 1996). Interestingly, the human SST-secreting cell line QGP-1, obtained from a neuroendocrine pancreatic tumour, expresses IFN- $\gamma$ receptors and IFN- $\gamma$ acts as a potent proapoptotic stimulus in these cells (Detjen et al. 2002). The present findings of antiproliferative and proapoptotic actions of IFN- $\gamma$ in cells derived from a human somatostatinoma tissue provide important clues for therapeutic strategies in this endocrine tumour.
Moreover, SS-C cells express telomerase activity, offering an additional target for pharmacological intervention in somatostatinoma. AZT is a molecule commonly used as an antiviral agent and also showing antitumour activity, probably via inhibition of chain elongation at the telomeric ends of chromosomes in cancer cells (Furman et al. 1986, Furman \& Barry 1988, Fischl et al. 1989, Posner et al. 1990, 1992, 1993, Beitz et al. 1992, Anand et al. 1995, Strahl \& Blackburn 1996, Furman et al. 2000). This study indicates that in vitro exposure of SS-C cells to AZT results in inhibition both of telomerase and of cell proliferation. We also found that AZT induced an apoptotic cell death in SS-C cells, as previously shown in Herpes virus-associated lymphomas (Lee et al. 1999) and in parathyroid carcinoma (Falchetti et al. 2005).

Finally, the inhibitory effect of SST-28, IFN- $\gamma$ and AZT on SS-C cell proliferation was additive, opening the possibility of the use of these agents in in vivo treatment of somatostatinoma.

In summary, these results characterize SST-28, octreotide, IFN- $\gamma$, and AZT as antiproliferative and proapoptotic stimuli in human somatostatinoma cells in long-term culture. These findings have a number of implications. First, this delineation in a human cellular model provides important clues on targets that might be analysed in vivo and/or in vitro to predict therapeutic responsiveness in somatostatinoma patients. Secondly, the use of anticancer agents that induce tumour apoptosis would probably lessen patient morbidity from complications of tumour lysis. Thirdly, based on these results, the potential of combined treatment with active compounds in experimental biotherapeutic treatment of somatostatinoma should be explored.

\section{Acknowledgements}

This paper has been supported by AIRC 2000 (to M L B), by Cofin MIUR 2003 (to F T) and by Fondazione Ente Cassa di Risparmio di Firenze (to M L B). The authors declare that there is no conflict of interest that would prejudice the impartiality of this scientific work.

\section{References}

Anand A, Ellis M, Tessitore J, Huberman M, Parker LM, Stuart K \& Posner MR 1995 A Phase I study of intermittent high-dose zidovudine, 5-fluorouracil, leucovorin and cisplatin. Proceedings of the American Society of Clinical Oncology 14481. 
Angeletti S, Corleto VD, Schillaci O, Marignani M, Annibale B, Moretti A, Silecchia G, Scopinaro F, Basso N, Bordi C et al. 1998 Use of the somatostatin analogue octreotide to localize and manage somatostatinproducing tumours. Gut 42 792-794.

Arnold R, Trautmann ME, Creutzfeldt W, Benning R, Benning M, Neuhaus C, Jurgensen R, Stein K, Schafer H, Bruns C et al. 1996 Somatostatin analogue octreotide and inhibition of tumor growth in metastatic endocrine gastroenteropancreatic tumors. Gut 38 430-438.

Beitz JG, Darnowski JW, Cummings FJ, Browne M, Clark J, Bigley J \& Weitberg A 1992 A Phase I and pharmacologic analysis of fluorouracil + leucovorin combined with infused high-dose zidovudine. Proceedings of the American Association for Cancer Research 33427.

Bordi C, D’Adda T, Azzoni C \& Ferraro G 1996 The somatostatin cell. Progress in Basic and Clinical Pharmacology 10 2-22.

Cheng Y \& Prussof WH 1973 Relationship between the inhibition constant $\left(\mathrm{K}_{\mathrm{i}}\right)$ and the concentration of an inhibitor which causes 50 per cent inhibition $\left(\mathrm{I}_{50}\right)$ of an enzymatic reaction. Biochemical Pharmacology 22 3099-3108.

Detjen KM, Kehrberger JP, Drost A, Rabien A, Welzel M, Wiedenmann B \& Rosewicz S 2002 Interferon- $\gamma$ inhibits growth of human neuroendocrine carcinoma cells via induction of apoptosis. International Journal of Oncology 21 1133-1140.

Falchetti A, Becherini L, Martineti V, Morelli A, Benvenuti S, Picariello L, Gennari L, Lampugnani R, Bordi C \& Brandi ML 1999 Telomerase repeat amplificaion protocol (TRAP): a new molecular marker for parathyroid carcinoma. Biochemical and Biophysical Research Communications 265 252-255.

Falchetti A, Franchi A, Bordi C, Mavilia C, Masi L, Cioppi F, Recenti R, Picariello L, Marini F, Del Monte F et al. 2005 Azidothymidine reduces apoptosis and inhibits cell growth and telomerase activity of human parathyroid cancer cells in culture. Journal of Bone and Mineral Research 20 410-418.

Fischl MA, Richman DD, Causey DM, Grieco MH, Bryson Y, Mildvan D, Laskin OL, Groopman JE, Volberding PA, Schooley RT et al. 1989 Prolonged zidovudine therapy in patients with AIDS and advanced AIDS-related complex. AZT Collaborative Working Group. Journal of the American Medical Association 262 2405-2410.

Florio T, Thellung S, Corsaro A, Bocca L, Arena S, Pattarozzi A, Villa V, Massa A, Diana F, Schettini D et al. 2003 Characterization of the intracellular mechanisms mediating somatostatin and lanreotide inhibition of DNA synthesis and growth hormone release from dispersed human GH-secreting pituitary adenoma cells in vitro. Clinical Endocrinology 59 115-128.

Furman PA \& Barry DW 1988 Spectrum of antiviral activity and mechanism of action of zidovudine. An overview. American Journal of Medicine 85 176-181.
Furman PA, Fyfe JA, St Clair MH, Weinhold K, Rideout JL, Freeman GA, Lehrman SN, Bolognesi DP, Broder S, Mitsuya $\mathrm{H}$ et al. 1986 Phosphorylation of $3^{\prime}$-azido$3^{\prime}$-deoxythymidine and selective interaction of the $5^{\prime}$-triphosphate with human immunodeficiency virus reverse transcriptase. PNAS 83 8333-8337.

Furman PA, Painter GR \& Anderson KS 2000 An analysis of the catalytic cycle of HIV-1 reverse transcriptase: opportunities for chemotherapeutic intervention based on enzyme inhibition. Current Pharmaceutical Design 6 547-567.

Gan Y, Engelke KJ, Brown CA \& Au JLS 2001 Telomere amount and length assay. Pharmacological Research $\mathbf{1 8}$ 1655-1659.

Hoyer O, Bell GI, Berelowitz M, Epelbaum J, Feniuk W, Humphrey PP, O'Carroll AM, Patel YC, Schonbrunn A, Taylor JE et al. 1995 Classification and nomenclature of somatostatin receptors. Trends in Pharmacological Sciences 16 86-88.

Iguchi H, Hayashi I \& Kono A 1990 A somatostatinsecreting cell line established from a human pancreatic islet cell carcinoma (somatostatinoma): release experiment and immunohistochemical study. Cancer Research $\mathbf{5 0}$ 3691-3693.

Jensen RT \& Norton JA 1993 Endocrine tumors of the pancreas. In Gastrointestinal Disease: Pathophysiology/ Diagnosis/Management, pp 1695-1721. Eds MH Sleisinger \& JS Fordtran. Philadelphia: WB Saunders Co.

Kim NW, Piatyszek MA, Prowse KR, Harley CB, West MD, Ho PL, Coviello GM, Wright WE, Weinrich SL \& Shay JW 1994 Specific association of human telomerase activity with immortal cells and cancer. Science $\mathbf{2 6 6}$ 2011-2015.

Konomi K, Chijiiwa K, Katsuta T \& Yamaguchi K 1990 Pancreatic somatostatinoma: a case report and review of the literature. Journal of Surgical Oncology 43 259-265.

Lee RK, Cai JP, Deyev V, Gill PS, Cabral L, Wood C, Agarwal RP, Xia W, Boise LH, Podack E et al. 1999 Azidothymidine and interferon- $\alpha$ induce apoptosis in herpesvirus-associated lymphomas. Cancer Research 59 5514-5520.

Liu Q, Reubi JC, Wang Y, Knoll BJ \& Schonbrunn A 2003 In vivo phosphorylation of the somatostatin $2 \mathrm{~A}$ receptors in human tumours. Journal of Clinical Endocrinology and Metabolism 88 6073-6079.

Lowry OH, Rosebrough NJ, Farr AL \& Randall RJ 1951 Protein measurement with the Folin reagent. Journal of Biological Chemistry 193 265-275.

Mezey E, Hunyady B, Mitra S, Hayes E, Liu Q, Schaeffer J \& Schonbrunn A 1998 Cell specific expression of the SST2A and SST5 somatostatin receptors in the rat anterior pituitary. Endocrinology 139 414-419.

Naasani I, Seimiya H \& Tsuruo T 1998 Telomerase inhibition, telomere shortening, and senescence of cancer cells by tea catechins. Biochemical and Biophysical Research Communications 249 391-396. 
Papotti M, Bongiovanni M, Volante M, Allia E, Landolfi S, Helboe L, Schindler M, Cole SL \& Bussolati G 2002 Expression of somatostatin receptor types 1-5 in 81 cases of gastrointestinal and pancreatic endocrine tumors. Virchows Archiv 440 461-475.

Platanias LC \& Fish EN 1999 Signaling pathways activated by interferons. Experimental Hematology 27 1583-1592.

Posner MR, Darnowski JW, Calabresi P, Brunetti I, Corvese D, Curt G, Cummings FJ, Clark J, Browne MJ \& Beitz J 1990 Oral zidovudine, continuous-infusion fluorouracil, and oral leucovorin calcium: a phase I study. Journal of the National Cancer Institute 82 1710-1714.

Posner MR, Darnowski JW, Weitberg AB, Dudley MN, Corvese D, Cummings FJ, Clark J, Murray C, Clendennin N, Bigley J et al. 1992 High-dose intravenous zidovudine with 5-fluorouracil and leucovorin. A phase I trial. Cancer 70 2929-2934.

Posner MR, Darnowski JW, Tessitore J, Bigley J, Parker LM, Stuart K \& Huberman MA 1993 A Phase I trial of high dose, intravenous zidovudine (AZT) and 5fluorouracil/leucovorin (FUra/L). Proceedings of the American Society of Clinical Oncology 12162.

Reubi JC, Waser B, Liu Q, Laissue JA \& Schonbrunn A 2000 Subcellular distribution of somatostatin sst2A receptors in human tumors of the nervous and neuroendocrine systems: membranous versus intracellular location.
Journal of Clinical Endocrinology and Metabolism $\mathbf{8 5}$ 3882-3891.

Sangfelt O, Erickson S \& Grander D 2000 Mechanisms of interferon-induced cell cycle arrest. Frontiers in Bioscience 5 D479-D487.

Sassolas G \& Chayvialle JA 1995 GRFomas, somatostatinomas: clinical presentation, diagnosis and advances in management. Frontiers of Gastrointestinal Research 23 94-207.

Soule HD \& McGrath CM 1986 A simplified method for passage and long-term growth of human mammary epithelial cells. In Vitro Cellular and Developmental Biology 22 6-12.

Strahl C \& Blackburn EH 1996 Effects of reverse transcriptase inhibitors on telomere length and telomerase activity in two immortalized human cell lines. Molecular and Cellular Biology 16 53-65.

Tamura T, Ueda S, Yoshida M, Matsuzaki M, Mohri H \& Okubo T 1996 Interferon- $\gamma$ induces gene expression and enhances cellular susceptibility to apoptosis in the U937 leukemia cell line. Biochemical and Biophysical Research Communications 229 21-26.

Yang L, Berk SC, Rohrer SP, Mosley RT, Guo L, Underwood DJ, Arison BH, Birzin ET, Hayes EC, Mitra SW et al. 1998 Synthesis and biological activities of potent peptidomimetics selective for somatostatin receptor subtype 2. PNAS 95 10836-10841. 
